\title{
Iodothyronine Sulfotransferase Activity in Rat Uterus During Gestation
}

\author{
SING-YUNG WU, WEN-SHENG HUANG, DELBERT A. FISHER, WARNER H. FLORSHEIM, \\ DONALD L. ST. GERMAIN, AND VALERIE ANNE GALTON
}

\begin{abstract}
Nuclear Medicine and Medicine Services, Department of Veterans'Affairs Medical Center, Long Beach, CA 90822, U.S.A. [S-y.W., W.H.G.]; Department of Nuclear Medicine, Tri-Service General Hospital, Taipei, Taiwan 100 ROC [W-s.H.]; Perinatal Laboratory, Harbor-UCLA Medical Center, Torrance, CA 90509, U.S.A. [D.A.F.]; and Department of Physiology, Dartmouth Medical School, Lebanon, NH 03756, U.S.A. [D.L.S.G., V.A.G.]
\end{abstract}

\begin{abstract}
In developing mammals, we and others demonstrated that sulfation is an important pathway in the metabolism of thyroid hormone, and there is significant fetal-maternal transfer of sulfated iodothyronine. In the present study, we characterized a novel iodothyronine sulfotransferase (IST) in pregnant rat uterus. ${ }^{125}$ I-labeled 3,3'-diiodothyronine $\left(\mathrm{T}_{2}\right), \mathrm{T}_{3}, \mathrm{rT}_{3}$, and $\mathrm{T}_{4}$ were used as substrates with unlabeled 3'-phosphoadenosine-5'-phosphosulfate (PAPS) as the sulfate donor. Sulfated iodothyronine products were separated by Sephadex LH-20 column and further identified on reverse phase HPLC. We measured IST activity in pregnant rat uterus by incubating $1 \mu \mathrm{M}$ substrate, $50 \mu \mathrm{M}$ PAPS, and 50 $\mu \mathrm{g}$ cytosol protein, $\mathrm{pH} 7.2,30 \mathrm{~min}$ at $37^{\circ} \mathrm{C}$. The results show that the substrate preference of the uterine IST activity is: $\mathrm{T}_{2}>\mathrm{rT}_{3}$ $>\mathrm{T}_{3}>\mathrm{T}_{4}$; the $\mathrm{pH}$ optimum is 6.0 for $\mathrm{T}_{2}$. The $\mathrm{K}_{\mathrm{m}}$ and $V_{\max }$ (for gestational day 21 uterus) for $\mathrm{T}_{2}$ are $0.62 \mu \mathrm{M}$ and $3466 \mathrm{pmol} / \mathrm{mg}$ protein/h, respectively; for PAPS the values are $2.6 \mu \mathrm{M}$ and 1523 $\mathrm{pmol} / \mathrm{mg}$ protein/h, respectively. During pregnancy, the total
\end{abstract}

\section{ABSTRACT}

activities exhibit a U-shaped curve with minimum activity at day 13 of gestation; while a thermostable activity increases significantly near term. In summary, there is significant uterine IST that varies during pregnancy. The role of this uterine sulfotransferase activities in regulating the bioavailability of thyroid hormone in the developing fetus remains to be elucidated. (Pediatr Res 48: 847-851, 2000)

\section{ABBREVIATIONS}

IST, iodothyronine sulfotransferase

$\mathbf{T}_{2}, 3,3$ '-diiodothyronine

$\mathbf{T}_{3}, 3,3$ ',5-triiodothyronine

$\mathbf{r T}_{3}$, reverse $\mathrm{T}_{3}$

$\mathbf{T}_{\mathbf{4}}$, thyroxine

PAPS, 3'-phosphoadenosine-5'-phosphosulfate

D3, type III deiodinase activity

NP, nonpregnant
In developing mammals, deficiency or excess of thyroid hormones during the fetal and neonatal periods can lead to morphologic and functional abnormalities of the CNS (1-7). Three types of monodeiodinases, type 1, 2, and 3, have been identified in mammalian fetal tissues and are thought to play roles in the regulation of active hormone $\left(\mathrm{T}_{3}\right)$ generation in different tissues and organs which have specific temporal patterns of development $(8,9)$. Additionally, in ovine fetuses, we have shown that alternate sulfate pathways are major routes of thyroid hormone metabolism and that high concentrations of thyroid hormone sulfoconjugates, i.e. thyroxine $\left(\mathrm{T}_{4} \mathrm{~S}\right)$ and 3,3',5-triiodothyronine $\left(\mathrm{T}_{3} \mathrm{~S}\right)$ and their metabolites $\left(3,3^{\prime}, 5^{\prime}\right.$ -

Received March 3, 2000; accepted July 28, 2000.

Correspondence and reprint requests: Sing-yung Wu, Ph.D., Nuclear Medicine and Medical Services (115), VA-UCI Medical Center, 5901 E. 7th Street, Long Beach, CA 90822, U.S.A.

This work was supported by the Department of Veterans' Affairs, by NIH Grants HD-09020 and DK 42271 and the National Science Council, (ROC) NSC 82-0412-B-016-085. triiodothyronine, $\mathrm{rT}_{3} \mathrm{~S}$, and 3,3'-diiodothyronine, $\mathrm{T}_{2} \mathrm{~S}$ ), are present in the biologic fluids of human and ovine fetuses $(10-18)$. More recently, we detected significant levels of sulfated iodothyronines in the plasma of premetamorphic tadpoles before there are detectable amounts of nonconjugated thyroid hormones (19). Sulfoconjugation may accelerate further degradation and excretion of the thyroid hormone and may provide a reservoir for biologically active hormones such as $\mathrm{T}_{3}(20-22)$ and possibly $\mathrm{rT}_{3}$ and $\mathrm{T}_{2}(23,24)$, which can be recovered from sulfated iodothyronines by sulfatases in selective tissue where hormone action is required. In addition, by accelerating further deiodination, this could assist in recovering iodine for new hormone synthesis.

This sulfoconjugation may be linked with monodeiodination in regulating bioavailability of thyroid hormones in various tissues. Thyroid hormones are small diffusible lipophilic compounds that may be able to reach the fetus through the surrounding mammalian uterus. Recently, Galton et al. found high levels of type 3 monodeiodoinase activity in pregnant rat 
uterus, which suggests a possible role for this tissue in the regulation of the amount of maternal thyroid hormone that reaches the fetus (25). We hypothesize that iodothyronine sulfotransferase (IST) may be present in rat uterus and contribute significantly to regulation of the bioavailability of thyroid hormones to the fetus. In the present study, we characterized IST activity in the pregnant rat uterus at various gestational ages.

\section{MATERIALS AND METHODS}

Animals. Timed-pregnant rats (12-14 wk old) were purchased from the Charles River Laboratory (North Wilmington, MA, U.S.A.). Rats were housed under conditions of controlled lighting and temperature until killed for study between gestational day (d) 9 and $\mathrm{d} 21$. Virgin female rats of comparable age were purchased from the same vendor to provide control data in the nonpregnant uterus. All animal protocols were approved by the Animal Use Subcommittee at the VA Medical Center, Long Beach, CA, U.S.A.

Sulfotransferase assay. Rats were killed by decapitation under anesthesia by intraperitoneal infusion of ketamine (20 $\mu \mathrm{g} / \mathrm{kg}$ ). The uterus was rapidly removed and dissected free of surrounding adipose tissue. It was then cross-sectioned to separate the individual implantation site. At $\mathrm{d} 9$ and $\mathrm{d} 11$ no further dissection was performed. At d13 to d21, the implantation site was opened by making a longitudinal cut along the antimesometrial side of the uterine wall. This part of the uterus lies directly on the dorsal side of the fetus and is on the opposite side of the attachment of the placenta to the fetus. The uterus was folded back over the amniotic sac containing the fetus and the placenta, and was then gently peeled free from these tissues. The amniotic sac, fetus, and placenta were then separated.

Uterine tissue was homogenized in $0.25 \mathrm{M}$ sucrose, $10 \mathrm{mM}$ HEPES, and $1 \mathrm{mM}$ DTT (pH 7.0) and the cytosol was prepared by centrifuging at $105,000 \times g$ for $1 \mathrm{~h}$. Protein was measured by a modified Lowry Method (26). Sulfotransferase activities were assayed in duplicates using the modified method of Kaptein and coworkers (20). In brief, $1 \mu \mathrm{M} \mathrm{T}_{2}$ (or $\mathrm{T}_{3}, \mathrm{rT}_{3}$, or $\mathrm{T}_{4}$ ) was incubated at $37^{\circ} \mathrm{C}$ for $30 \mathrm{~min}$ with $100,000 \mathrm{cpm}$ of the

${ }^{125}$ I-labeled compound in the presence or absence (blank) of 50 $\mu \mathrm{M}$ PAPS in $0.2 \mathrm{~mL}$ of $0.1 \mathrm{M}$ phosphate $(\mathrm{pH} 7.2)$ and $2 \mathrm{mM}$ EDTA (assay buffer). The reactions were started by addition of cytosol diluted in ice-cold assay buffer and stopped by addition of $0.8 \mathrm{~mL} 0.1 \mathrm{~N} \mathrm{HCl}$. The mixtures were applied to a Sephadex LH-20 minicolumn (bed volume $1 \mathrm{~mL}$ ) equilibrated with 2 volumes of $0.1 \mathrm{~N} \mathrm{HCl}$. Iodide, sulfated iodothyronines, and nonsulfated iodothyronines were successively eluted with $3 \times$ $1 \mathrm{~mL} 0.1 \mathrm{~N} \mathrm{HCl}, 8 \times 1 \mathrm{~mL}$ ethanol:water (20:80, vol:vol), and $4 \times 1 \mathrm{~mL}$ ethanol/0.1 N NaOH (50:50, vol:vol), respectively. One- milliliter fractions were collected and counted for radioactivity. Sulfation in complete reaction mixtures was corrected by subtracting PAPS blank. The results are the means of 2-3 separate experiments and are specified in the legends of figures. Sulfated iodothyronines were further identified by highpressure liquid chromatography ( $\mu$ Bondapak $\mathrm{C}_{18}$ column) iso- cratically with a mixture of acetonitrile and $0.02 \mathrm{M}$ ammonium acetate, $\mathrm{pH} 4.0$ (22:78, vol:vol) as described previously (22).

Sources of materials. $3,3^{\prime}-\mathrm{T}_{2}, \mathrm{~T}_{3}, 3,3^{\prime}, 5^{\prime}-\mathrm{T}_{3}\left(\mathrm{rT}_{3}\right)$ and $\mathrm{T}_{4}$ were purchased from Henning-Berlin (Berlin, Germany) [3'$\left.{ }^{125} \mathrm{I}\right]$. - $\mathrm{rT}_{3},-\mathrm{T}_{4},-\mathrm{T}_{3}$, and $-\mathrm{T}_{2}$ were prepared by radioiodination using the method previously described (27). PAPS, DTT and Sephadex LH-20 were purchased from Sigma Chemical Co. Chemical (St. Louis, MO, U.S.A.)

Statistical analysis. Student's unpaired $t$ test was used to compare differences between groups. Analysis of variance was used to test the multigroup comparisons. If significant differences were present, Dunnett's multicomparison test was used to compare the control or baseline mean and the mean values of other groups (28). Significance was defined as $p<0.05$. Results are reported as means \pm SE.

\section{RESULTS}

Characterization of rat uterine iodothyronine sulfotransferase activity. In preliminary experiments, sulfation of labeled iodothyronines, $\mathrm{T}_{2}, \mathrm{rT}_{3}, \mathrm{~T}_{3}$, and $\mathrm{T}_{4}$ increased linearly with increasing concentrations of cytosol protein at $30 \mathrm{~min}$ incubation. At optimal enzyme concentrations, the production of sulfated iodothyronines is linear with time up to $1 \mathrm{~h}$ (results not shown). We further found no significant deiodination in the uterine cytosol preparations when incubated up to $3 \mathrm{~h}$ with labeled iodothyronines. Figures 1 and 2 compare the effect of increasing concentrations of unlabeled $\mathrm{T}_{2}, \mathrm{rT}_{3}, \mathrm{~T}_{3}$, and $\mathrm{T}_{4}$ on the sulfation of radioactive $\mathrm{T}_{2}$ and $\mathrm{rT}_{3}$, respectively, by rat $\mathrm{d} 21$ pregnant uterine cytosol in the presence of PAPS. The dose inhibition curves for unlabeled $\mathrm{rT}_{3}$ and $\mathrm{T}_{2}$ were very similar when their effects on sulfation of radioactive $\mathrm{T}_{2}$ and $\mathrm{rT}_{3}$ were compared. In both cases $\mathrm{IC}_{50}$ values were nearly 1.5 times



Figure 1. Effect of $1-20 \mu \mathrm{M}$ unlabeled $3,3^{\prime}-\mathrm{T}_{2}, \mathrm{rT}_{3}, \mathrm{~T}_{3}$ and $\mathrm{T}_{4}$ on the sulfation of $3,\left[3^{\prime}-{ }^{125} \mathrm{I}\right] \mathrm{T}_{2}$ by rat $\mathrm{d} 21$ pregnant uterine cytosol in the presence of $50 \mu \mathrm{M}$ PAPS and $30 \mathrm{~min}$ incubation at $37^{\circ} \mathrm{C}$. Results are the means of two separate experiments. 


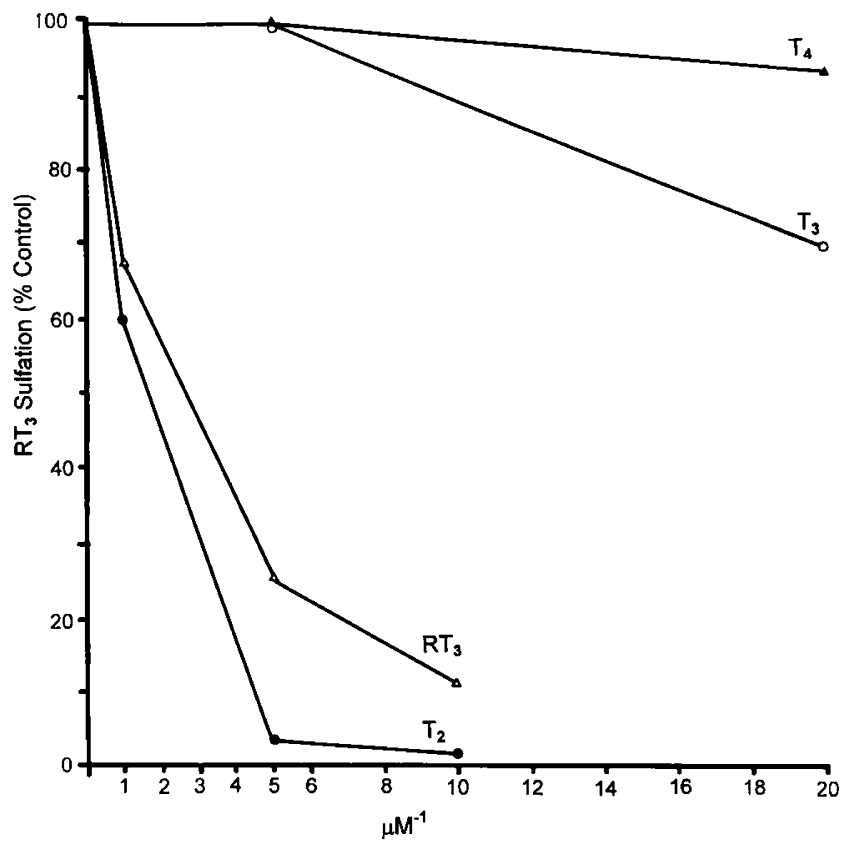

Figure 2. Effect of $1-20 \mu \mathrm{M}$ unlabeled $\mathrm{T}_{3}$ and $\mathrm{T}_{4}$ and1-10 $\mu \mathrm{M}$ unlabeled $3,3^{\prime}-\mathrm{T}_{2}$ and $\mathrm{rT}_{3}$ on the sulfation of $3,5^{\prime},\left[3^{\prime}-{ }^{125} \mathrm{I}\right] \mathrm{T}_{3}$ by rat $21 \mathrm{~d}$ pregnant uterine cytosol in the presence of $50 \mu \mathrm{M}$ PAPS, $250 \mu \mathrm{g}$ protein $/ \mathrm{mL}$ and $30 \mathrm{~min}$ incubation at $37^{\circ} \mathrm{C}$. The means of two separate experiments are shown.

higher for $r T_{3}$ than for $T_{2}$. These results suggest $T_{2}$ and $r T_{3}$ (and possibly $\mathrm{T}_{3}$ ) are substrates for sulfotransferase isoenzyme(s) that is (are) more readily saturated by $\mathrm{T}_{2}$, and $\mathrm{rT}_{3}$ than by $\mathrm{T}_{3}$.

Figure 3 shows the effects of $\mathrm{pH}$ on the sulfation of $\mathrm{T}_{2}$ by uterine tissue from virgin (NP) and $\mathrm{d} 21$ pregnant rat. In both preparations, peak $\mathrm{T}_{2}$ sulfation rates were observed at $\mathrm{pH}$ 6.0. However, all subsequent experiments were performed at a more physiologic $\mathrm{pH}$ of 7.2.

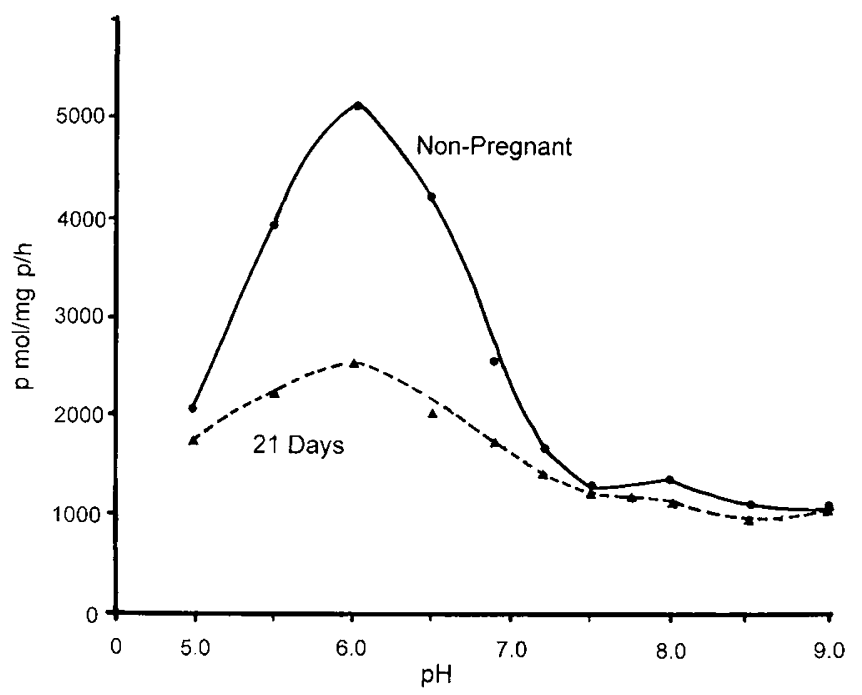

Figure 3. Effect of $\mathrm{pH}$ on sulfation of $3,3^{\prime}-\mathrm{T}_{2}$ by nonpregnant (NP) and $\mathrm{d} 21$ pregnant uterine cytosol in $1 \mu \mathrm{M} 3,\left[3^{\prime}-{ }^{125} \mathrm{I}\right] \mathrm{T}_{2}, 250 \mu \mathrm{g}$ cytosolic protein $/ \mathrm{mL}$, $50 \mu \mathrm{M}$ PAPS and $30 \mathrm{~min}$ incubation. Results are the means of 2-3 separate experiments.
The double reciprocal plots of sulfation rates (in pmol/mg protein/h) versus $\mathrm{T}_{2}$ concentration $(\mu \mathrm{M})$ were linear allowing the calculation of apparent $\mathrm{K}_{\mathrm{m}}$ for $\mathrm{T}_{2}$ and $V_{\max }$ (at $50 \mu \mathrm{M}$ PAPS). Table 1 presents the kinetic data $(n=3-5)$ showing that the apparent $\mathrm{K}_{\mathrm{m}}$ value for $\mathrm{T}_{2}$ for $\mathrm{d} 21$ was similar to uterine cytosol from NP, d8, d10, and d19.

The double reciprocal plots of increasing PAPS concentration $(0.5-10 \mu \mathrm{M})$ on the sulfation of $1 \mu \mathrm{M} \mathrm{T} \mathrm{T}_{2}$ by NP, and pregnant uterine cytosol were linear. In all preparations, $T_{2}$ sulfation approached maximum rates at PAPS concentration near $10 \mu \mathrm{M}$. The kinetic data from 3-4 such experiments in each gestational period are shown in Table 1, showing that the apparent $\mathrm{K}_{\mathrm{m}}$ value for PAPS is slightly higher in NP than in d21 uterus; but there is no significant statistical difference.

From Figure 4 an apparent $\mathrm{K}_{\mathrm{m}}$ value of $3.7 \mu \mathrm{M}$ and $V_{\max }$ of $77 \mathrm{pmol} / \mathrm{mg} \mathrm{p} / \mathrm{h}$ were calculated for $\mathrm{T}_{3}$ sulfation by uterine cytosol from NP rats in the presence of $50 \mu \mathrm{M}$ PAPS. Therefore, the apparent $\mathrm{K}_{\mathrm{m}}$ value for $\mathrm{T}_{3}$ is higher and the $V_{\max }$ value is much lower than the corresponding values for $\mathrm{T}_{2}$ sulfation.

Gestational changes of iodothyronine sulfotransferase activity and their thermostability. In Figure 5, the IST activities in uterus tissue from the pregnant rats are plotted versus gestation age. The activities show a U-shaped curve with a minimum activity at $\mathrm{d} 13$ and higher values at $\mathrm{d} 8$ and $\mathrm{d} 21$. There was also significant IST activities in the uterine tissue from nonpregnant (NP) rats. However, when heated to $45^{\circ} \mathrm{C}$ for $15 \mathrm{~min}$, only about $4.2 \%$ of $\mathrm{T}_{2}$-ST remained in NP, while $67.0 \%(p<0.01 \mathrm{cf}$. NP) was stable in the $\mathrm{d} 21$ pregnant uterus. The thermostable IST activity increased significantly near term at $\mathrm{d} 21$.

\section{DISCUSSION}

The present studies demonstrate the presence of IST activity in rat uterine cytosol. The enzyme activity has a substrate preference for $\mathrm{T}_{2}\left(\mathrm{~T}_{2}>\mathrm{rT}_{3}>\mathrm{T}_{3}>\mathrm{T}_{4}\right)$ and a pH-optimum of 6.0. The most interesting finding is that the activity appears to be gestation age dependent, especially the thermostable $\left(45^{\circ} \mathrm{C}\right.$ $\times 5 \mathrm{~min}$ ) form, which increase significantly near term. The uterine sulfotransferase activity is clearly quite different from

Table 1. Gestational Changes of Kinetic Parameters of $T_{2}$ Sulfation by Rat Uterine Cytosol*

\begin{tabular}{lrccc}
\hline & & $N$ & $K_{m}$ & $V_{\max }$ \\
\hline $3,3^{\prime}-T_{2}{ }^{* *}$ & $\mathrm{NP}$ & 3 & $0.58 \pm 0.06$ & $2733 \pm 120$ \\
& $\mathrm{~d} 8$ & 3 & $1.05 \pm 0.05$ & $2600 \pm 200$ \\
& $\mathrm{~d} 10$ & 3 & $0.50 \pm 0.08$ & $1065 \pm 235$ \\
& $\mathrm{~d} 13$ & 3 & $1.53 \pm 0.21$ & $565 \pm 115$ \\
& $\mathrm{~d} 19$ & 3 & $1.00 \pm 0.23$ & $1310 \pm 690$ \\
PAPS & $\mathrm{d} 21$ & 5 & $0.62 \pm 0.18$ & $3466 \pm 1438$ \\
& $\mathrm{NP}$ & 4 & $3.3 \pm 0.3$ & $1507 \pm 59$ \\
& $\mathrm{~d} 8$ & 3 & $2.9 \pm 0.3$ & $730 \pm 45$ \\
& $\mathrm{~d} 10$ & 3 & $3.7 \pm 1.2$ & $583 \pm 94$ \\
& $\mathrm{~d} 13$ & - & - & - \\
& $\mathrm{d} 19$ & 3 & $2.6 \pm 0.3$ & $363 \pm 37$ \\
& $\mathrm{~d} 21$ & 3 & $2.6 \pm 0.5$ & $1523 \pm 442$ \\
\hline
\end{tabular}

Data are presented as mean $\pm \mathrm{SE} \mu \mathrm{M}\left(\mathrm{K}_{\mathrm{m}}\right)$ or pmoles $\mathrm{T}_{2} \mathrm{~S} / \mathrm{mg}$ prot./h. $\left(\mathrm{V}_{\max }\right)$ with number of experiments $(\mathrm{N})$ indicated.

* Values are calculated from double-reciprocal plots; ** Determined at 50 $\mu \mathrm{M}$ PAPS 




Figure 4. Double-reciprocal plot of the effect of substrate concentration on the sulfation of $\mathrm{T}_{3}$ by a NP rat uterine cytosol. Reactions were conducted in duplicated in $0.04-2 \mu \mathrm{M} 3,5,\left[3^{\prime}-{ }^{125} \mathrm{I}\right]-\mathrm{T}_{3}, 50 \mu \mathrm{M}$ PAPS, $1 \mathrm{mg}$ cytosol protein for $60 \mathrm{~min}$ at $37^{\circ} \mathrm{C}$. Results are the means of $2-3$ separate experiments.

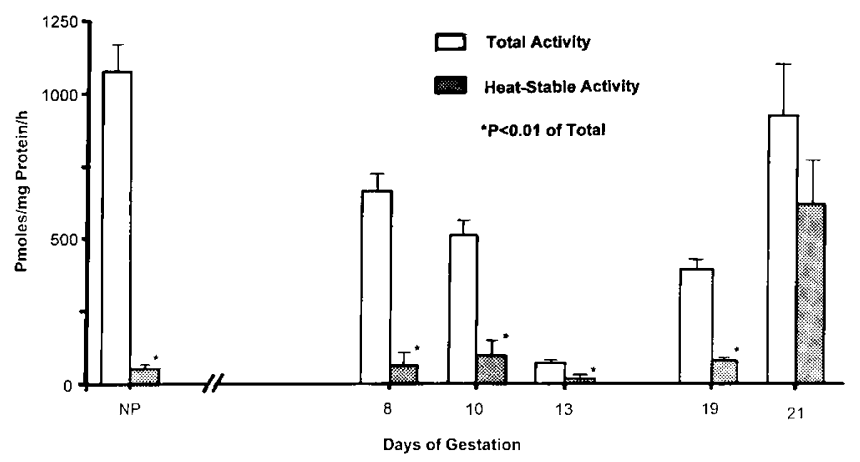

Figure 5. Effect of gestational changes on sulfation of 3,3'- $\mathrm{T}_{2}$ by pregnant uterus cytosol: from NP to $\mathrm{d} 21$ gestation. The open bar represents total activities and the shaded bar represents thermostable activity after heating up at $45^{\circ} \mathrm{C}$ for $5 \mathrm{~min}$. Reactions ( $n=3-5$ separate experiments) were conducted in $1 \mu \mathrm{M} 3,\left[3^{\prime}-{ }^{125} \mathrm{I}_{2}, 250 \mu \mathrm{g}\right.$ protein $/ \mathrm{mL}, 50 \mu \mathrm{M}$ PAPS and $30 \mathrm{~min}$ incubation.

rat hepatic isozyme (rSULT1C1), which has a pH-optimum of 8.0 and a substrate preference of $\mathrm{T}_{2}>\mathrm{T}_{3}>\mathrm{rT}_{3}>\mathrm{T}_{4}(21)$. In addition, the apparent Michaelis-Menton $\left(\mathrm{K}_{\mathrm{m}}\right)$ value for $\mathrm{T}_{2}$ is lower $(0.50-1.53 \mu \mathrm{M})$ in uterus than in liver $(4.9 \mu \mathrm{M}$ for female rats). At $1 \mu \mathrm{M} \mathrm{T}_{2}$ and $\mathrm{pH}$ 7.2, the apparent $\mathrm{K}_{\mathrm{m}}$ values for PAPS were similar in uterus and liver [2.6-3.7 $\mu \mathrm{M}$ and 3.8 $\mu \mathrm{M}$ (for female rats), respectively]. Kester et al. reported that human estrogen sulfotransferase (SULT1E1), which is expressed in the uterus and possibly also in the placenta, is also found to sulfoconjugate iodothyronines (29). However, SULT1E1 has a much higher $\mathrm{K}_{\mathrm{m}}$ to $\mathrm{T}_{2}(3.5-6.0 \mu \mathrm{M})$ and to $\mathrm{T}_{3}$ $(15.3-36.1 \mu \mathrm{M})$ than the cytosol enzyme in rat uteri in the present study. Presently, one cannot exclude the possibility that a similar rat SULT1E1 may conjugate both estrogen and thyroid hormone as shown in the human. In addition, the uterine IST is quite different from human SULT1A1 and SULT1A3 (30). Although the $\mathrm{pH}$ optimum is similar to the phenolsulfotransferase (EC 2.8.2.1) described in rat brains, sulfation of iodothyronines was not measured in that study (31).

Recently, Galton et al. found high levels of type III deiodinase activity (D3) in pregnant rat uterus (25). Furthermore, by in situ hybridization, both D3 mRNA and activity were present at the implantation site as early as gestational age $\mathrm{d} 9$ before placental development. Notably, the levels of D3 in the pregnant uterus are even higher than those in the placenta, which were determined at the same stage of gestation, and are much higher than those in either the whole fetus or in the individual fetal organs. At later stages of gestation, uterine D3 activities remains very high (25). These findings suggest that pregnant uterus plays an important role in modulating fetal exposure to maternal thyroid hormone. The present studies demonstrate significant levels of sulfotransferase activities, using D3 metabolites $\left(\mathrm{T}_{2}\right.$ and $\left.\mathrm{rT}_{3}\right)$ as preferred substrates, in the pregnant rat uterus. This appears to suggest a potential role for the sulfation pathway in regulating, together with uterine and placental D3, the amount of maternal thyroid hormones that reach the fetus. It is interesting that the uterine sulfotransferase activities may be under gestational regulation with a minimum level of both thermostable and thermolabile activities around d13 that coincides with localization of expression of D3 in the epithelial cells lining the uterine lumen that surrounds the fetal cavity (25). This is consistent with the hypothesis that uterine IST is an added mechanism linked with D3 to optimize maternal to fetal transfer of thyroid hormone in the developing fetus before and after the onset of fetal thyroid function (d18-19) $(25,32)$.

The sulfoconjugation of thyroid hormones $\left(\mathrm{T}_{4}\right.$ and $\left.\mathrm{T}_{3}\right)$ and their metabolites $\left(\mathrm{rT}_{3}\right.$ and $\left.\mathrm{T}_{2}\right)$ may accelerate further degradation and excretion of iodothyronines. Sulfated iodothyronine may also serve as a reservoir for biologically active hormones such as $T_{3}$, which can be recovered from $\mathrm{T}_{3} \mathrm{~S}$ by sulfatases in selective tissue in which hormone action is required (21). Sulfated $\mathrm{T}_{3}$ may be metabolized to active hormone by tissue sulfatase particularly in situations when type 1 deiodinating activity is low, e.g. fetal state and nonthyroidal illnesses (33, 34). The purpose of rapid sulfation of $3,3^{\prime}-\mathrm{T}_{2}$ and $\mathrm{rT}_{3}$ by uterine IST is unknown. Both metabolites have little affinity for the nuclear thyroid hormone receptor $(34,35)$. However, recently, 3, 3'- $T_{2}$ has been found to stimulate mitochondrial respiration in various rat tissues (23) and $\mathrm{rT}_{3}$ may play a role in regulating actin polymerization in brain cells (24). Thus, the possibility that these $T_{4}$ metabolites may play a physiologic role in developing animal cannot be excluded. In addition, we have demonstrated that sulfoconjugation facilitates fetal to maternal transfer of thyroid hormones and their metabolites, sulfated 3,3'- $\mathrm{T}_{2}$ in particular $(18,36)$. It is possible that uterine sulfotransferase may be involved in such a transfer process.

Acknowledgments. The authors thank Ms. Gail Jones and Ms. Cynthia Simons for their efforts in helping out in the experiments, Ms. Hien Q. On for her secretarial assistance.

\section{REFERENCES}

1. Daneman D, Howard NJ 1980 Neonatal thyrotoxicosis: intellectual impairment and craniosynostosis in later years. J Pediatr 97:257-259

2. Harakawa S, Akazawa S, Akazawa M, Hashimoto M, Yamshita S, Izumi M, Nagataki S 1989 Changes of serum thyroid hormone levels induce malformations on early embryogenesis in rats. Acta Endocrinol 121:739-743

3. Kopp P, Van Sande J, Parma J, Duprez L, Gerber H, Joss E, Jameson JL, Dumont JE, Vassart G 1995 Congenital hyperthyroidism caused by a mutation in the thyrotropinreceptor gene. N Engl J Med 332:150-154 
4. Nicholson JL, Altman J 1972 The effects of early hypo- and hyperthyroidism on the development of rat cerebellar cortex: I. Cell proliferation and differentiation. Brain Res 44:13-23

5. Nicholson JL, Altman J 1972 The effects of early hypo- and hyperthyroidism on the development of rat cerebellar cortex: II. Synaptogenesis in the molecular layer. Brain Res 44:25-36

6. Pasquini JM, Adamo AM 1994 Thyroid hormones and the central nervous system. Dev Neurosci 16:1-8

7. Porterfield SP, Hendrich CE 1993 The role of thyroid hormones in prenatal and neonatal neurological development - current perspectives. Endocr Rev 14:94-106

8. Bates JM, St Germain DL, Galton VA 1999 Expression of profiles of the three iodothyronine deiodinases, $\mathrm{D}_{1}, \mathrm{D}_{2}$, and $\mathrm{D}_{3}$ in the developing rat. Endocrinology 140:844-851

9. Wu SY, Fisher DA, Polk D, Chopra IJ 1991 Maturation of thyroid hormone metabolism. In: Wu SY (ed) Thyroid Hormone Metabolism, Regulation and Clinical Implications. Blackwell, Boston, pp 293-230

10. Wu SY, Polk D, Wong S, Reviczky A, Vu R, Fisher DA 1992 Thyroxine sulfate is a major thyroid hormone metabolite and a potential intermediate in the monodeiodination pathways in fetal sheep. Endocrinology 131:1751-1756

11. Wu SY, Huang WS, Polk D, Florsheim WH, Green WL, Fisher DA 1992 Identification of thyroxine-sulfate $\left(\mathrm{T}_{4} \mathrm{~S}\right)$ in human serum and amniotic fluid by a novel $\mathrm{T}_{4} \mathrm{~S}$ radioimmunoassay. Thyroid 2:101-105

12. Chopra IJ, Wu SY, Chua Teco GN, Santini F 1992 A radioimmunoassay for measurement of 3, 5, 3' - triiodothyronine sulfate: Studies in thyroidal and nonthyroidal diseases, pregnancy, and neonatal life. J Clin Endocrinol Metab 75:189-194

13. Wu SY, Polk DH, Huang WS, Reviczky A, Wang K, Fisher DA 1993 Sulfate conjugates of iodothyronines in developing sheep: effect of fetal hypothyroidism. Am J Physiol 265 (Endocrinol Metab 28):E115-E120

14. Wu SY, Huang WS, Polk D, Chen WL, Reviczky A, Williams J III, Chopra IJ, Fisher DA 1993 The development of a radioimmunoassay for reverse triiodothyronine sulfate in human serum and amniotic fluid. J Clin Endocrinol Metab 76:1625-1630

15. Wu SY, Polk DH, Chen WL, Fisher DA, Huang WS, Yee B 1994 A 3,3' -diiodothyronine sulfate cross-reactive compound in serum from pregnant women. J Clin Endocrinol Metab 78:1505-1509

16. Polk DH, Reviczky A, Wu SY, Huang WS, Fisher DA 1994 Metabolism of sulfoconjugated thyroid hormone derivatives in developing sheep. Am J Physiol 266 (Endocrinol Metab 29): E892-E895

17. Polk DH, Fisher DA, Wu SY 1994 Alternate pathways of thyroid hormone metabolism in developing mammals. In: Wu SY, Visser TJ (eds) Thyroid Hormone Metabolism: Molecular Biology and Alternate Pathways. CRC Press, Boca Raton, pp 223-243

18. Wu SY, Polk D, Fisher DA, Huang WS, Reviczky A, Chen WL 1995 Identification of 3,3' $-\mathrm{T}_{2} \mathrm{~S}$ as a fetal thyroid hormone derivative in maternal urine in sheep. Am J Physiol 268 (Endocrinol Metab 31):E33-E39

19. Wu SY, Huang WS, Polk DH, Parker LN, Fisher DA, Galton VA 1998 Sulfoconjugation is a major pathway of thyroid hormone metabolism in developing animals from tadpoles to mammals. Program 80th Annual Meeting of the Endocrine Society: 248
20. Kaptein E, VanHaasteren GAC, Linkels E, DeGreef WJ, Visser TJ 1997 Characterization of iodothyronine sulfotransferase activity in rat liver. Endocrinology 138:5136-5143

21. Visser TJ 1994 Sulfation and glucuronidation pathway of thyroid hormone metabolism. In: Wu SY, Visser TJ (eds) Thyroid Hormone Metabolism: Molecular Biology and Alternate Pathways. CRC Press, Boca Raton, pp 85-117

22. Wu SY, Fisher A, Huang WS, Beck-Peccoz P, Emerson CH, Kuo W, Chen W 1998 Urinary compound $\mathrm{W}$ in pregnant women is a potential marker for fetal thyroid function. Am J Obstet Gynecol 178:885-891

23. Moreno M, Lanni A, Lombardi A, Goglia F 1997 How the thyroid controls metabolism in the rat: different roles for triiodothyronine and diiodothyronines. J Physiol 505:529-538

24. Leonard JL, Farwell A 1997 Thyroid hormone-regulated actin polymerization in brain. Thyroid 7:147-151

25. Galton VA, Martinez E, Hernandez A, St. Germain EA, Bates JM, St Germain DL 1999 Pregnant rat uterus expresses high levels of the type 3 iodothyronine deiodinase. J Clin Invest 103:979-987

26. Hartree SF 1972 Determination of protein: A modification of the Lowry method that gives a linear photometric response. Anal Biochem 48:422-427

27. Nakamura Y, Chopra IJ, Solomon DH 1977 Preparation of high specific activity radioactive iodothyronines and their analogues. J Nucl Med 18:1112-1115

28. Kirk RE 1982 Experimental Design, 2nd Ed, Brooks-Cole, Belmont, pp 112-114

29. Kester MHA, Van Dijk CH, Tibboel D, Hood Am, Rose NJM, Meinl W, Pabel U, Glatt H, Falany CN, Coughtrie MWH, Visser TJ 1999 Sulfation of thyroid hormone by estrogen sulfotransferase. J Clin Endocrinol Metab 84:2577-2580

30. Kester MHA, Kaptein E, Roest TJ, Van Dijk CH, Tibboel D, Meinl W, Glatt H, Goughtrie MWH, Visser TJ 1999 Characterization of human iodothyronine sulfotransferase. J Clin Endocrinol Metab 84:1357-1364

31. Anderson RJ 1994 Biochemical characterization of $T_{3}$ sulfotransferase. In: Wu SY, Visser TJ (eds) CRC Press, Boca Raton, pp 155-174

32. Morreale De Escobar G, Pastor R, Obregon MJ, Escobar Del Rey F 1985 Effects of maternal hypothyroidism on the weight and thyroid hormone content of rat embryonic tissues, before and after onset of fetal thyroid function. Endocrinology 117:18901900

33. Santini F, Hurd RE, Lee B, Chopra IJ 1993 Thyromimetic effects of 3,5,3'triiodothyronine sulfate $\left(\mathrm{T}_{3} \mathrm{~S}\right)$ in hypothyroid rat. Endocrinology 133:105-110

34. Chopra IJ, Santini F, Wu SY, Hurd RE 1994 The role of sulfation and desulfation in thyroid hormone metabolism. In: Wu SY, Visser TJ (eds) Thyroid Hormone Metabolism: Molecular Biology and Alternate pathways. CRC Press, Boca Raton, pp $119-138$

35. Oppenheimer JH, Schwartz HL 1997 Molecular basis of thyroid hormone-dependent brain development. Endocr Rev 18:462-475

36. Wu SY, Polk DH, Huang WS, Fisher DA 1999 Fetal-to-maternal transfer of 3,3',5triiodothyronine sulfate and its metabolite in sheep. Am J Physiol 268 (Endocrinol Metab 40):E915-E919 